\title{
Phenotypic and pathobiological properties of Corynebacterium aquaticum isolated from diseased striped bass
}

\author{
A. M. Baya ${ }^{1}$, B. Lupiani ${ }^{1, *}$, I. Bandín ${ }^{2}$, F. M. Hetrick ${ }^{1}$, A. Figueras ${ }^{3}$, A. Carnahan $^{1}$, \\ E. M. May ${ }^{4}$ A. E. Toranzo ${ }^{2}$ \\ ${ }^{1}$ Department of Microbiology, University of Maryland, College Park, Maryland 20742, USA \\ ${ }^{2}$ Departamento de Microbiología y Parasitología, Facultad de Biología, Universidad de Santiago de Compostela, E-15706, \\ Spain \\ ${ }^{3}$ Instituto de Investigaciones Marinas (CSIC), Eduardo Cabello 6, E-36208 Vigo, Spain \\ ${ }^{4}$ Oxford Cooperative Laboratory, 904 South Morris St., Oxiord, Maryland 21654, USA
}

\begin{abstract}
A Corynebacterium strain was isolated from the brain tissues of $3 \mathrm{yr}$ old striped bass Morone saxatilis with pronounced bilateral exophthalmia that were being held in experimental aquaculture facilities. Taxonomic analysis, using conventional tests and the API-Coryne system, allowed us to identify the striped bass strain (RB 968 BA) as Corynebacterium aquaticum. An agglutination assay demonstrated that the fish isolate was serologically related to the reference strain of C. aquaticum (ATCC 14665) originally isolated from water. Although both strains exhibited different surface protein patterns, immunoblot analysis revealed they shared a protein antigen of $68 \mathrm{kDa}$. Only the $C$. aquaticum from striped bass proved to be pathogenic for fish ( $L D_{50}$ values of $1.0 \times 10^{5}$ and $5.8 \times 10^{4}$ for striped bass and rainbow trout Oncorhynchus mykiss respectively) and mice $\left(\mathrm{LD}_{50}=\right.$ $8.3 \times 10^{4}$ ). Similarly, the extracellular products of this strain (but not of several other corynebacteria species aiso tested) possessed proteolytic activity, elicited a cytotoxic response in both fish and homoiothermic cell lines, showed dermonecrotic activity in rabbits, and contained exotoxins lethal for fish $\left(\mathrm{LD}_{50}=1.70 \mathrm{\mu g}\right.$ protein $\left.\mathrm{g}^{-1} \mathrm{fish}\right)$. All these biological activities, exhibited in vitro and in vivo, were concomitantly lost after heating $\left(100^{\circ} \mathrm{C}\right.$ for $\left.10 \mathrm{~min}\right)$. Histopathological examination showed lesions in the internal organs of experimentally infected fish. The brain and eyes were the most affected organs and showed acute hemorrhages. Personnel involved in culturing fish should be made aware of the pathogenic capability exhibited by C. aquaticum for mammals.
\end{abstract}

\section{INTRODUCTION}

Bacteria with characteristics resembling those of corynebacteria are commonly isolated during routine surveys of the microbiological quality of fish and water from either fresh or marine fish-rearing units (Austin \& Austin 1985, Toranzo et al. 1985, Cahill 1990). However, only occasional mention has been made of the role of coryneforms as fish pathogens (Austin et al. 1985). On the other hand, the number of reports of human and animal infections attributable to coryneform bacteria has increased steadily during the last few years (Collins \& Cummins 1986, Krech \& Hollis 1991). Corynebacterium aquaticum, originally found in both

- Present address: College of Veterinary Medicine, University of Maryland, College Park, Maryland 20742, USA distilled water and natural fresh waters, has been reported to produce disease in some immunocompromised patients (Lipsky et al. 1982, Beckwith et al. 1986, Kaplan \& Israel 1988, Tendler \& Bottone 1989). Despite its importance, C. aquaticum as well as other Corynebacterium species are neither included in Bergey's Manual of Systematic Bacteriology (Collins \& Cummins 1986) nor in the Approved Lists of Bacterial Names (Moore \& Moore 1989, Skerman et al. 1989).

During a disease outbreak in 3 yr old striped bass Morone saxatilis maintained in our experimental aquaculture facilities at the University of Maryland, USA, we isolated Corynebacterium aquaticum from the brain tissues of fish exhibiting pronounced bilateral exophthalmia. Since, to our knowledge, this is the first description of $C$. aquaticum as a potential fish pathogen, we carried out an extensive phenotypic and anti- 
genic characterization of this microorganism and investigated its pathogenic activities in vitro and in vivo for both fish and homoiothermic animals.

\section{MATERIALS AND METHODS}

Isolation conditions. In December 1990, a disease outbreak occurred in $3 \mathrm{yr}$ old striped bass being held in $1000 \mathrm{l}$ tanks in our laboratory facilities. The tanks were supplied with dechlorinated (charcoal-filtered) city water at $22^{\circ} \mathrm{C}$. The fish were fed commercial trout food and had been held in the facility for 2 mo before the outbreak, during which time they appeared to be quite healthy. The first sign of a problem was the appearance of exophthalmia in some striped bass. The disease developed slowly $(3 \mathrm{wk})$ and the fish did not exhibit any other external abnormalities. Gradually $50 \%$ of the bass in 1 tank developed unilateral exophthalmia that became bilateral and they stopped feeding. Diseased fish also swam more slowly than normal. Eventually the majority of striped bass were found dead with their eyes ruptured. Only in a few mild cases did the fish recover without therapy. Internal organs did not exhibit any gross abnormalities; however, the brain was hemorrhagic and the brain cavity was full of blood. Fish from the same group held in a separate tank did not show any signs of disease.

Microbiological examination. For bacterial isolation, samples taken from kidney, liver, eye and brain tissues were streaked onto trypticase soy and brain heart infusion agars (TSA and BHIA; Difco Laboratories, Detroit, MI, USA), and inoculated into brain heart infusion and tryptic soy broths (BHI and TSB; Difco). Plates and tubes were incubated at $25^{\circ} \mathrm{C}$ for 48 to $72 \mathrm{~h}$. In addition, samples from the water supply and the tank walls were also examined.

Pure cultures of the isolated colonies were subjected to standard morphological, physiological, and biochemical plate and tube tests (Smibert \& Krieg 1981, Krech \& Hollis 1991). The results were recorded after $7 \mathrm{~d}$ incubation at $25^{\circ} \mathrm{C}$. Since preliminary tests allowed us to identify the bacteria isolated from striped bass as a Gram positive organism belonging to the coryneform group, the commercial API-Coryne system (Biomerieux) was used in parallel with the conventional tests following the instructions of the manufacturer.

For the taxonomic tests, the reference strain of Corynebacterium aquaticum ATCC 14665 and several clinical corynebacteria (C. xerosis NCIB 9956, C. pseudodiphtheriticum ATCC 10700, and C. pseudotuberculosis ATCC 19410) were included for comparison. The majority of the biochemical tests in all the strains were conducted simultaneously at 25 and $37^{\circ} \mathrm{C}$.
Drug sensitivity of the isolates was determined by the disc diffusion method on Mueller-Hinton agar (Oxoid, Ltd, Basingstoke, Hampshire, England). The following chemotherapeutic agents ( $\mathrm{Hg} \mathrm{disc}^{-1}$ ) were employed: penicillin $G(10)$, ampicillin (10), chloramphenicol (30), erythromycin (15), tetracycline (30), oxytetracycline (30), streptomycin (10), oxolinic acid (2), nalidixic acid (5), furazolidone (100), nitrofurantoin (300), and trimethoprim-sulfomethoxazole (23.75-1.25).

Working cultures of the strains were maintained in tubes of soft agar (casitone, $0.1 \%$; yeast extract, $0.3 \%$; $\mathrm{NaCl}, 1 \%$; agar, $0.3 \%, \mathrm{pH} 7.2)$ under mineral oil. For long-term preservation, cultures were frozen at $-70^{\circ} \mathrm{C}$ in TSB with $15 \%(\mathrm{v} / \mathrm{v})$ glycerol.

To test for the possible presence of a viral agent, spleen, kidney, and brain tissues were removed from several fish, pooled, and processed following standard virological isolation procedures (Amos et al. 1985). The chinook salmon cmbryo (CHSE-214), and epithelioma papulosum cyprini (EPC) cell lines were utilized in the virological analysis. Cells were routinely cultivated at $15^{\circ} \mathrm{C}$ (CHSE-214) or $25^{\circ} \mathrm{C}$ (EPC) with Eagle's minimum essential medium (EMEM; Flow Laboratories) supplemented with $10 \%$ newborn calf serum. Maintenance medium consisted of EMEM with $2 \%$ calf serum.

Serological analysis. To examine the serological relationship among the Corynebacterium isolates, slide agglutination tests were conducted according to procedures described previously (Toranzo et al. 1987a). Antisera against the reference strain of Corynebacterium aquaticum and the striped bass isolate RB968BA were prepared by injecting rabbits intravenously with formalin-killed cells twice weekly in consecutive doses of $0.2,0.4,0.8$ and $1 \mathrm{ml}\left(10^{9}\right.$ cells $\left.\mathrm{ml}^{-1}\right)$. The rabbits were bled from the ear vein $1 \mathrm{wk}$ after the last injection. The blood was allowed to clot and the sera were separated and stored at $-20^{\circ} \mathrm{C}$ until used.

In addition, cross-quantitative agglutination tests were performed in microtitre plates using serial 2 -fold dilutions of $25 \mu$ l aliquots of the antisera (Roberson et al. 1990). The titer was considered as the reciprocal of the highest dilution of the antiserum which gave a positive reaction after overnight incubation with the antigen at $30^{\circ} \mathrm{C}$. To test for possible cross reactions with other Gram positive fish pathogens, agglutination assays were also conducted with antisera raised against reference strains of Renibacterium salmoninarum ATCC 33209 and Carnobacterium (formerly Lactobacillus) piscicola ATCC 35586.

Virulence for fish. The striped bass strain RB 968BA, and the reference strains, were tested for pathogenicity in fingerling striped bass $(8 \mathrm{~g})$ and rainbow trout Oncorhynchus mykiss $(10 \mathrm{~g})$ maintained at $20^{\circ} \mathrm{C}$, in freshwater aquaria with aeration. After bacteriological 
examination of the fish stocks showed them to be negative, infectivity trials were conducted by intraperitoneal (i.p.) inoculation of bacterial doses ranging from $10^{2}$ to $10^{8}$ cells ( 6 fish being used per dose) as previously described (Toranzo et al. 1983a). Mortalities were recorded daily over a 3 wk period and the lethal dose $50 \%\left(\mathrm{LD}_{50}\right)$ calculated by the Reed \& Müench method (1938). Fish surviving the challenge were sacrificed and reisolation of the inoculated strain was attempted to assess a possible carrier state.

Mouse pathogenicity. To assess the degree of virulence of the Corynebacterium isolates for homoiothermic animals, a mouse virulence assay was performed. Between 5 and $10 \mathrm{BALB} / \mathrm{c}$ mice (10 to $12 \mathrm{wk}$ old, 21 to $25 \mathrm{~g})$ were i.p. inoculated with doses ranging from $10^{4}$ to $10^{8} \mathrm{CFU}$ of each Corynebacterium strain. Mortalities were recorded daily and the $\operatorname{LD}_{50}$ calculated after $7 \mathrm{~d}$ according to Reed \& Müench (1938). Strains displaying an $\mathrm{LD}_{50}<10^{7} \mathrm{CFU}$ were considered virulent (Daily et al. 1981)

Surface protein extraction and gel electrophoresis. Membrane proteins from the Corynebacterium strains were prepared as previously described (Toranzo et al. 1983a). Bacterial cultures grown in TSB were centrifuged at $7000 \times \mathrm{g}$ for $10 \mathrm{~min}$ at $4{ }^{\circ} \mathrm{C}$ and cellular pellets were resuspended in $3 \mathrm{ml}$ of $10 \mathrm{mM}$ Tris- $\mathrm{HCl}$ buffer ( $\mathrm{pH} 8.0$ ) with $0.3 \% \mathrm{NaCl}$. The pellets were then disrupted by sonic treatment (Bronson sonifier 250). After centrifugation at $10000 \times g$ for $1 \mathrm{~min}$, the supernatant fluids were transferred to other tubes and centrifuged again for $60 \mathrm{~min}$ at $20000 \times \mathrm{g}$ at $4{ }^{\circ} \mathrm{C}$. The resultant pellets were suspended in distilled water. These suspensions were frozen at $-30^{\circ} \mathrm{C}$ until used. Prior to electrophoresis, the samples were boiled for 5 min in buffer containing $65 \mathrm{mM}$ Tris- $\mathrm{HCl}$ ( $\mathrm{pH}$ 6.8), $2 \%$ SDS, $10 \%(\mathrm{v} / \mathrm{v})$ glycerol, $0.001 \%$ bromophenol blue and $5 \% 2$-mercaptoethanol. Sodium dodecyl sulfate polyacrylamide gel electrophoresis (SDS-PAGE) was carried out overnight at constant current $(20 \mathrm{~mA})$ using $12.5 \%$ acrylamide in the separating gel and $3 \%$ in the stacking gel (Laemmli 1970). After electrophoresis, the gels were stained following the method of Tsai \& Frasch (1982) and the relative mobilities of the proteins determined by comparison with a mixture of known molecular weight (MW) markers (Bio-Rad).

Western blotting. After electrophoresis, proteins were electroblotted from the gel onto nitrocellulose (NC) membranes $(0.45 \mu \mathrm{m}$, Bio-Rad) and reacted with antisera using a modification of the method of Towbin et al. (1979). The transfer buffer consisted of $25 \mathrm{mM}$ $\mathrm{HCl}$ (pH 8.3), $192 \mathrm{mM}$ glycine, and $20 \%$ methanol. After transfer, NC membranes were blocked for $1 \mathrm{~h}$ with $3 \%$ gelatin in Tris-buffered saline (TBS), $\mathrm{pH} 7.5$, before immunostaining.

Gelatin-blocked membranes were washed in TSB plus $0.05 \%$ Tween 20 (TTBS) and then incubated for $1 \mathrm{~h}$ in control or immune rabbit serum diluted $1: 1000$ in TTBS containing $1 \%$ gelatin. After further washing in TTBS, membranes were incubated for $1 \mathrm{~h}$ with goat anti-rabbit IgG-alkaline phosphatase conjugate (BioRad) diluted 1:3000. Bands were visualized by incubating $\mathrm{NC}$ membranes in $0.1 \mathrm{M}$ carbonate buffer ( $\mathrm{pH}$ 9.8) containing tetrazolium blue $\left(0.3 \mathrm{mg} \mathrm{ml}^{-1}\right)$ and 5-bromo-4-chloro-3-indolyl phosphate $p$-toluidine salt $\left(0.15 \mathrm{mg} \mathrm{ml}^{-1}\right)$. Finally, blots were rinsed in distilled water for ca 3 min and dried.

Preparation of extracellular products. The extracellular products (ECP) of the Corynebacterium strains were obtained by the cellophane plate technique (Liu 1957). Briefly, sterilized cellophane sheets were placed on TSA plates and inoculated by spreading $0.5 \mathrm{ml}$ of a $24 \mathrm{~h}$ old broth culture of each strain over the surface with a sterile swab. After incubation at $25^{\circ} \mathrm{C}$ for $48 \mathrm{~h}$, cells were washed off the cellophane with phosphate buffered saline (PBS, pH 7.4). The cell suspensions were centrifuged at $10000 \times g$ for $30 \mathrm{~min}$ at $4^{\circ} \mathrm{C}$ and the resulting supernatants were filter-sterilized $\left(0.45 \mu \mathrm{m}\right.$ pore size) and stored at $-30^{\circ} \mathrm{C}$ until required. The protein concentrations of the ECP samples were determined by the method of Bradford (1976) using bovine serum albumin as standard.

Detection of enzymatic activities in the ECP. To determine the total proteolytic activity present in the ECP samples a non-specific protease substrate (Azocoll, Sigma) was employed. The assay was performed according to the manufacturer's instructions. One unit of protease activity produced an absorbance reading of 1.0 at $520 \mathrm{~nm}$ after a 30 min assay at $37^{\circ} \mathrm{C}$.

Caseinase and gelatinase activities were determined by a radial diffusion method using a basal nutrient agar (BNA) (peptone, $4 \mathrm{~g} \mathrm{l}^{-1}$; yeast extract, $1 \mathrm{~g} \mathrm{l}^{-1}$; agar, $15 \mathrm{~g}$ $\mathrm{1}^{-1}$ ) containing $1 \%$ sodium caseinate (Difco) or $1.5 \%$ gelatin (Oxoid), respectively. Drops $(10 \mu \mathrm{l})$ of each ECP were placed on the plates and incubated at $22^{\circ} \mathrm{C}$ for 24 to $48 \mathrm{~h}$. To enhance visualization of cleared zones around the inocula, plates of gelatin were flooded with $15 \%(\mathrm{w} / \mathrm{v})$ mercuric chloride in $20 \%(\mathrm{v} / \mathrm{v}) \mathrm{HCl}$. One unit of caseinase or gelatinase activity was defined as that amount which gave a zone of clearing equal in area to that produced by $1 \mu \mathrm{g}$ trypsin (Sigma) (Bandín et al. 1989). The production of phospholipase was quantified by a similar method using BNA containing $1 \%(\mathrm{v} / \mathrm{v}) \mathrm{egg}$ yolk emulsion (Oxoid). Plates were incubated for $48 \mathrm{~h}$, and the titer expressed as the reciprocal of the highest dilution of crude ECP producing an opaque zone around the inoculum $(10 \mu l)$. Hemolytic activity was measured in microtiter plates using $2 \%$ sheep erythrocytes and the titer expressed as the reciprocal of the highest dilution of ECP producing complete hemolysis.

The stability of all the enzymatic activities was 
assayed after heating the ECP samples at $80^{\circ} \mathrm{C}$ and $100^{\circ} \mathrm{C}$ for $10 \mathrm{~min}$.

Cytotoxic activities of the ECP. The ECP preparations were assayed for cytotoxicity as previously described (Toranzo et al. 1983b) in the following fish and homoiothermic cell lines: CHSE-214, EPC, FHM (Fathead minnow peduncle), BF-2 (peduncle of bluegill fry), L-929 (mouse lung fibroblast) and Vero (African green monkey kidney) cells. Monolayers grown in 24well plates were inoculated with $100 \mu \mathrm{l}$ of serial dilutions of each ECP and incubated at $18^{\circ} \mathrm{C}$ (fish cell lines) or $37^{\circ} \mathrm{C}$ (mammalian cell lines). Total or partial destruction of monolayers within a $2 \mathrm{~d}$ period was scored as a positive cytotoxic effect. Results were expressed as the minimal amount of ECP protein necessary to produce a cytotoxic response. Samples heated at $80^{\circ} \mathrm{C}$ and $100^{\circ} \mathrm{C}$ for $10 \mathrm{~min}$ were also tested.

Toxicity of the ECP for fish and mice. The lethal effects of exotoxins produced by the Corynebacterium strains for fish and mammals were evaluated by i.p. inoculation of rainbow trout and mice respectively with $0.1 \mathrm{ml}$ of each ECP sample. Groups of 6 fish, maintained under the conditions described above for the virulence assays, were used per dose (serial 2-fold dilutions of the ECP). Mortalities were monitored over $7 \mathrm{~d}$ and the $\mathrm{LD}_{50}$ (expressed as $\mu \mathrm{g}$ ECP protein $\mathrm{g}^{-1}$ body $w \mathrm{t}$ of fish) calculated. In the case of mice, groups of 5 to 10 animals were inoculated only with undiluted ECP samples and the lethal effects expressed as no. of dead mice per no. of inoculated mice. Control fish and mice were injected with $0.1 \mathrm{ml}$ of PBS.

Detection of dermonecrotic factor. The presence of vascular permeability factors in the ECP was determined following the procedures of Oliver et al. (1981). Briefly, $0.1 \mathrm{ml}$ of each ECP sample was injected intradermally in the back of shaved New Zealand rabbits ( $1 \mathrm{~kg}$ body $w \mathrm{t}$ ). The rabbits were euthanized and skinned $20 \mathrm{~h}$ post-inoculation. The presence of edematous and or hemorrhagic zones with a diameter $>0.8 \mathrm{~cm}$ was considered a positive test. Positive ECP samples were also tested after treatment at $100^{\circ} \mathrm{C}$ for $10 \mathrm{~min}$.

Histopathological examination. Tissues (brain, kidney, liver, spleen, intestine) from moribund fish in the experimental infections were fixed whole in $4 \%$ buffered formalin and $1 \%$ glutaraldehyde for $24 \mathrm{~h}$ and then transverse sections, ca 2 to $3 \mathrm{~mm}$ thick, were made from each organ. The tissue samples were embedded in paraffin and $5 \mu \mathrm{m}$ sections were stained with iron hematoxylin and eosin.

In all of the in vivo and in vitro virulence studies, 2 recognized fish pathogens, Aeromonas hydrophila strain B-32 and Vibrio anguillarum strains 43-F isolated from rainbow trout and striped bass in Spain and the USA respectively (Toranzo et al. 1987b, Santos et al. 1988), were also included.

\section{RESULTS AND DISCUSSION}

\section{Isolation and characterization of the causative organism}

Microbiological examination revealed the absence of bacterial growth from the kidney or liver of diseased striped bass in any of the culture media. However, we recovered bacteria from the brain of 9 and 11 fish examined but only from liquid media (TSB and BHI). The streaking of positive tubes onto TSA plates showed the growth to represent a pure culture. Colonies (1 to $3 \mathrm{~mm}$ diameter) were round, raised, entire, opaque, slightly viscid, and exhibited a yellow non-diffusible pigment after $48 \mathrm{~h}$ incubation at $25^{\circ} \mathrm{C}$ on solid media.

The taxonomic characterization (Table 1) showed the isolated organism (representative strain RB 968BA) to be a motile, nonspore-forming, non-acid fast, Gram positive rod ca 0.5 to $0.8 \mu \mathrm{m} \times 1$ to $3 \mu \mathrm{m}$ in size. The organism exhibited slight pleomorphism with the appearance of some club-shaped forms and typical angular arrangements of cells ('Coryne' forms). The bacterium was oxidase negative but catalase positive and did not produce acid in the oxidative-fermentative test. All these characteristics indicated it could belong to the coryneform group and presumptively to the genus Corynebacterium. The results of additional physiological and biochemical conventional tests, and the profile generated in the API-Coryne system compared to reference Corynebacterium strains, allowed us to identify the isolate from striped bass as Corynebacterium aquaticum. The microorganism grew over a wide temperature $\left(4\right.$ to $42^{\circ} \mathrm{C}$ ) and salinity (0 to $\left.5 \% \mathrm{NaCl}\right)$ range.

Like the ATCC strain, the isolate from striped bass was biochemically unreactive as it did not produce arginine dihydrolase, lysine or ornithine decarboxylases, phospholipase, and indole; citrate was not utilized, and it failed to produce acid from any of the carbohydrates tested. However, both strains displayed a positive Voges-Proskauer reaction, produced $\beta$ galactosidase and hydrolyzed esculin. Interestingly, only the Corynebacterium aquaticum from striped bass, but not any of the other corynebacteria, displayed proteolytic (caseinase and gelatinase) activities. A common feature of all the strains tested was that the hemolytic activity was expressed only at $37^{\circ} \mathrm{C}$. Although we obtained excellent identification (>99\% confidence level) of both $C$. aquaticum strains using the API-Coryne System, some discrepancies in the sugar reactions were observed with respect to the description of this species reported by Krech \& Hollis (1991). These differences may be due to the different experimental procedures employed as well as to the interpretation of the results (i.e. utilization of carbohydrates as cited by Krech \& Hollis, vs fermentation of sugars as described 
Table 1. Comparison of the characteristics exhibited by the Corynebacterium aquaticum strain isolated from striped bass (RB 968BA) with the reference strain (ATCC 14665) and other clinical corynebacteria. +: Positive reaction; -: negative reaction; $(+)$ : weak and delayed positive reaction; R: resistant strain; S: sensitive strain; I: intermediate strain; ND: not determined

\begin{tabular}{|c|c|c|c|c|c|}
\hline \multirow[b]{2}{*}{ Test } & \multicolumn{2}{|c|}{ Corynebacterium aquaticum } & \multicolumn{3}{|c|}{ Clinical corynebacteria } \\
\hline & RB 968BA & ATCC 14665 & $\begin{array}{c}\text { C. xerosis } \\
\text { NCIMB } 9956\end{array}$ & $\begin{array}{l}\text { C. pseudodiph- } \\
\text { theriticum } \\
\text { ATCC } 10700\end{array}$ & $\begin{array}{c}\text { C. pseudotuber- } \\
\text { culosis } \\
\text { ATCC } 19410\end{array}$ \\
\hline \multicolumn{6}{|l|}{ Conventional methods } \\
\hline Gram stain & + & + & + & + & + \\
\hline Motility & + & + & - & - & - \\
\hline Oxidase & - & - & - & - & - \\
\hline Catalase & + & + & + & + & + \\
\hline Pigment & Yellowish & Yellowish & - & - & - \\
\hline Voges-Proskauer & + & + & - & - & - \\
\hline Indole production & - & - & - & - & - \\
\hline Citrate utilization & - & - & - & - & - \\
\hline $\mathrm{H}_{2} \mathrm{~S}$ production & - & - & - & - & - \\
\hline $\mathrm{O} / \mathrm{F}$ glucose & $-1-$ & $-1-$ & $+1+$ & $-1-$ & $+1+$ \\
\hline Gas from glucose & - & - & - & - & - \\
\hline Arginine dihydrolase & - & - & - & - & - \\
\hline Lysine decarboxylase & - & - & - & - & - \\
\hline Ornithine decarboxylase & - & - & - & - & - \\
\hline Growth at $4^{\circ} \mathrm{C}$ & + & - & - & - & - \\
\hline Growth at $25^{\circ} \mathrm{C}$ & + & + & + & + & + \\
\hline Growth at $35^{\circ} \mathrm{C}$ & + & + & + & + & + \\
\hline Growth at $42^{\circ} \mathrm{C}$ & + & + & - & + & $(+)$ \\
\hline Growth in $0 \% \mathrm{NaCl}$ & + & + & + & + & + \\
\hline Growth in $3 \% \mathrm{NaCl}$ & + & + & + & + & $(+)$ \\
\hline Growth in $5 \% \mathrm{NaCl}$ & $(+)$ & - & - & + & - \\
\hline Growth in $8 \% \mathrm{NaCl}$ & - & - & - & - & - \\
\hline \multicolumn{6}{|l|}{ Growth on selective media } \\
\hline MacConkey agar & - & - & ND & ND & ND \\
\hline KF-Streptococcus agar & - & - & - & - & - \\
\hline Esculin hydrolysis & + & + & - & - & - \\
\hline Gelatinase & + & - & - & - & - \\
\hline Caseinase & + & - & - & - & - \\
\hline Phospholipase & - & - & - & - & - \\
\hline Hemolysis (sheep blood) ${ }^{a}$ & $+\beta$ & $+\beta$ & $+\beta$ & $+\beta$ & $+\beta$ \\
\hline \multicolumn{6}{|l|}{ API-Coryne system } \\
\hline Nitrate reduction & - & + & + & + & - \\
\hline Pyrazinamidase & + & + & + & + & - \\
\hline Pyrrolidonyl arylamidase & + & - & - & + & - \\
\hline Alkaline phosphatase & + & + & + & + & + \\
\hline$\beta$-glucuronidase & - & - & - & - & - \\
\hline$\beta$-galactosidase (ONPG) & + & + & - & - & + \\
\hline$\alpha$-glucosidase & + & + & - & - & - \\
\hline $\mathrm{N}$-acetyl- $\beta$-glucosaminidase & - & + & - & - & - \\
\hline Esculin ( $\beta$-glucosidase) & + & + & - & - & - \\
\hline Urease & - & - & - & + & + \\
\hline Gelatin hydrolyis & $(+)$ & - & - & - & - \\
\hline \multicolumn{6}{|l|}{ Fermentation of } \\
\hline Glucose & - & - & + & - & + \\
\hline Ribose & - & - & + & - & + \\
\hline Xylose & - & - & - & - & - \\
\hline Mannitol & - & - & - & - & - \\
\hline Maltose & - & - & - & - & - \\
\hline Lactose & - & - & - & - & - \\
\hline Sucrose & - & - & - & - & - \\
\hline Glycogen & - & - & - & - & - \\
\hline
\end{tabular}

(Table continued on next page) 
Table 1 (continued)

\begin{tabular}{|c|c|c|c|c|c|}
\hline \multirow[b]{2}{*}{ Test } & \multicolumn{2}{|c|}{ Corynebacterium aquaticum } & \multicolumn{3}{|c|}{ Clinical corynebacteria } \\
\hline & RB 968BA & ATCC 14665 & $\begin{array}{c}\text { C. xerosis } \\
\text { NCIMB } 9956\end{array}$ & $\begin{array}{l}\text { C. pseudodiph- } \\
\text { theriticum } \\
\text { ATCC } 10700\end{array}$ & $\begin{array}{l}\text { C. pseudotuber- } \\
\text { culosis } \\
\text { ATCC } 19410\end{array}$ \\
\hline \multicolumn{6}{|l|}{ Resistance/sensitivity to } \\
\hline Penicillin G & $\mathrm{R}$ & $\mathrm{R}$ & $\mathrm{R}$ & $\mathrm{R}$ & $\mathrm{R}$ \\
\hline Ampicillin & $\mathrm{S}$ & $S$ & $\mathrm{~S}$ & $\mathrm{~S}$ & $\mathrm{~S}$ \\
\hline Chloramphenicol & I & $\mathrm{S}$ & $\mathrm{S}$ & S & $\mathrm{S}$ \\
\hline Tetracycline & I & $S$ & $\mathrm{~S}$ & $\mathrm{~S}$ & $\mathrm{~S}$ \\
\hline Oxytetracycline & $S$ & $\mathrm{~S}$ & $\mathrm{~S}$ & $\mathrm{~S}$ & $\mathrm{~S}$ \\
\hline Streptomycin & $\mathrm{R}$ & $\mathrm{S}$ & I & $s$ & $\mathrm{R}$ \\
\hline Erythromycin & $\mathrm{S}$ & $\mathrm{S}$ & ND & ND & ND \\
\hline Oxolonic acid & $\mathrm{R}$ & $\mathrm{R}$ & $\mathrm{R}$ & $\mathrm{R}$ & $\mathrm{R}$ \\
\hline Nalidixic acid & $\mathrm{R}$ & $\mathrm{R}$ & $\mathrm{R}$ & $\mathrm{R}$ & $\mathrm{R}$ \\
\hline Furazolidone & $\mathrm{R}$ & $\mathrm{R}$ & $\mathrm{R}$ & $\mathrm{R}$ & $\mathrm{R}$ \\
\hline Nitrofurantoin & $\mathrm{R}$ & $\mathrm{R}$ & $\mathrm{R}$ & $\mathrm{R}$ & $\mathrm{R}$ \\
\hline $\begin{array}{l}\text { Trimethoprim- } \\
\text { sulfamethoxazole }\end{array}$ & $\mathrm{S}$ & $\mathrm{S}$ & $\mathrm{S}$ & I & $\mathrm{S}$ \\
\hline
\end{tabular}

in our study). All the Corynebacterium strains displayed a similar drug susceptibility pattern being resistant to penicillin, oxolinic acid, nalidixic acid, furazolidone, and nitrofurantoin (Table 1). However, $C$. aquaticum from striped bass was sensitive to oxytetracycline and erythromycin which proved to be useful antibiotics for the control of fish infections by Gram positive bacteria such as Renibacterium salmoninarum (Evelyn et al. 1986, Brown et al. 1990, Bandín et al. 1991)

We also recovered Corynebacterium aquaticum from the holding water as well as from the rim of 'scum' that is formed on the tank walls at the air-water interface. These isolates possessed the same characteristics as those shown by the striped bass isolate. We were not able to isolate the organism from the water supply to the laboratory.

Attempts to isolate virus in the CHSE-214 and EPC cell lines were negative both on the primary isolation attempt and after 2 blind passages

The results of agglutination assays using antisera raised against the Corynebacterium aquaticum strains

Table 2. Origin, serology, and virulence for fish of the Corynebacterium strains used in this study. The agglutination titer in parentheses was the reciprocal of the highest dilution of antiserum that gave a positive reaction after an overnight incubation at $30^{\circ} \mathrm{C}$. Lethal dose $50 \%\left(\mathrm{LD}_{50}\right)$ : no. of bacteria needed to kill $50 \%$ of inoculated specimens; + virulence; $(+):$ low degree of virulence; - : no virulence; ND: not determined

\begin{tabular}{|c|c|c|c|c|c|c|}
\hline \multirow[t]{2}{*}{ Strains } & \multirow[t]{2}{*}{ Origin } & \multicolumn{2}{|c|}{$\begin{array}{l}\text { Agglutination with } \\
\text { rabbit antiserum to }\end{array}$} & \multicolumn{2}{|c|}{$\begin{array}{l}\text { Virulence for fish } \\
\text { (LDso) }\end{array}$} & \multirow{2}{*}{$\begin{array}{l}\text { Virulence } \\
\text { for mice } \\
\left(L D_{50}\right)\end{array}$} \\
\hline & & $\mathrm{RB} 968 \mathrm{BA}$ & ATC 14665 & $\begin{array}{l}\text { Striped } \\
\text { bass }\end{array}$ & $\begin{array}{c}\text { Rainbow } \\
\text { trout }\end{array}$ & \\
\hline \multicolumn{7}{|l|}{ Corynebacterium aquaticum } \\
\hline $\mathrm{RB} 968 \mathrm{BA}$ & Striped bass & $+(2048)$ & $+(512)$ & $+\left(1.0 \times 10^{5}\right)$ & $+\left(5.8 \times 10^{4}\right)$ & $+\left(8.3 \times 10^{4}\right)$ \\
\hline ATCC 14665 & Distilled water & $+(256)$ & $+(>4096)$ & $-\left(>1.0 \times 10^{8}\right)$ & $-\left(>8.0 \times 10^{7}\right)$ & $-\left(>6.4 \times 10^{7}\right)$ \\
\hline \multicolumn{7}{|l|}{ Clinical corynebacteria } \\
\hline C. xerosis NCIMB 9956 & Human & - & - & ND & $-\left(>9.2 \times 10^{7}\right)$ & $-\left\{>1.0 \times 10^{8}\right\}$ \\
\hline $\begin{array}{l}\text { C. pseudodiphtheriticum } \\
\text { ATCC } 10700\end{array}$ & Human & - & - & ND & $-\left(>2.0 \times 10^{8}\right)$ & $-\left(>8.6 \times 10^{7}\right)$ \\
\hline $\begin{array}{l}\text { C. pseudotuberculosis } \\
\text { ATCC } 19410\end{array}$ & Sheep & - & - & ND & $(+)\left(4.5 \times 10^{6}\right)$ & $+\left(1.2 \times 210^{6}\right)$ \\
\hline \multicolumn{7}{|l|}{ Controls } \\
\hline Aeromonas hydrophila B-32 & Rainbow trout & - & - & ND & $+\left(3.2 \times 10^{4}\right)$ & $+\left(1.0 \times 10^{6}\right)$ \\
\hline Vibrio anguillarum 43-F & Striped bass & - & - & $+\left(3.0 \times 10^{2}\right)$ & $+\left(4.5 \times 10^{3}\right)$ & $+\left(4.0 \times 10^{5}\right)$ \\
\hline
\end{tabular}


demonstrated that both the striped bass isolate and the ATCC reference strain were serologically related, although the heterologous titers were lower than the homologous ones (Table 2). No cross reactions were detected with the clinical corynebacteria strains. In addition, serological tests conducted using antisera against Renibacterium salmoninarum and Corynebacterium piscicola were negative, which ruled out a non-specific reaction between these Gram positive bacteria and other coryneform organisms (Austin et al. 1985)

The analysis of membrane proteins showed that the Corynebacterium aquaticum isolated from fish possessed a protein pattern different from the reference

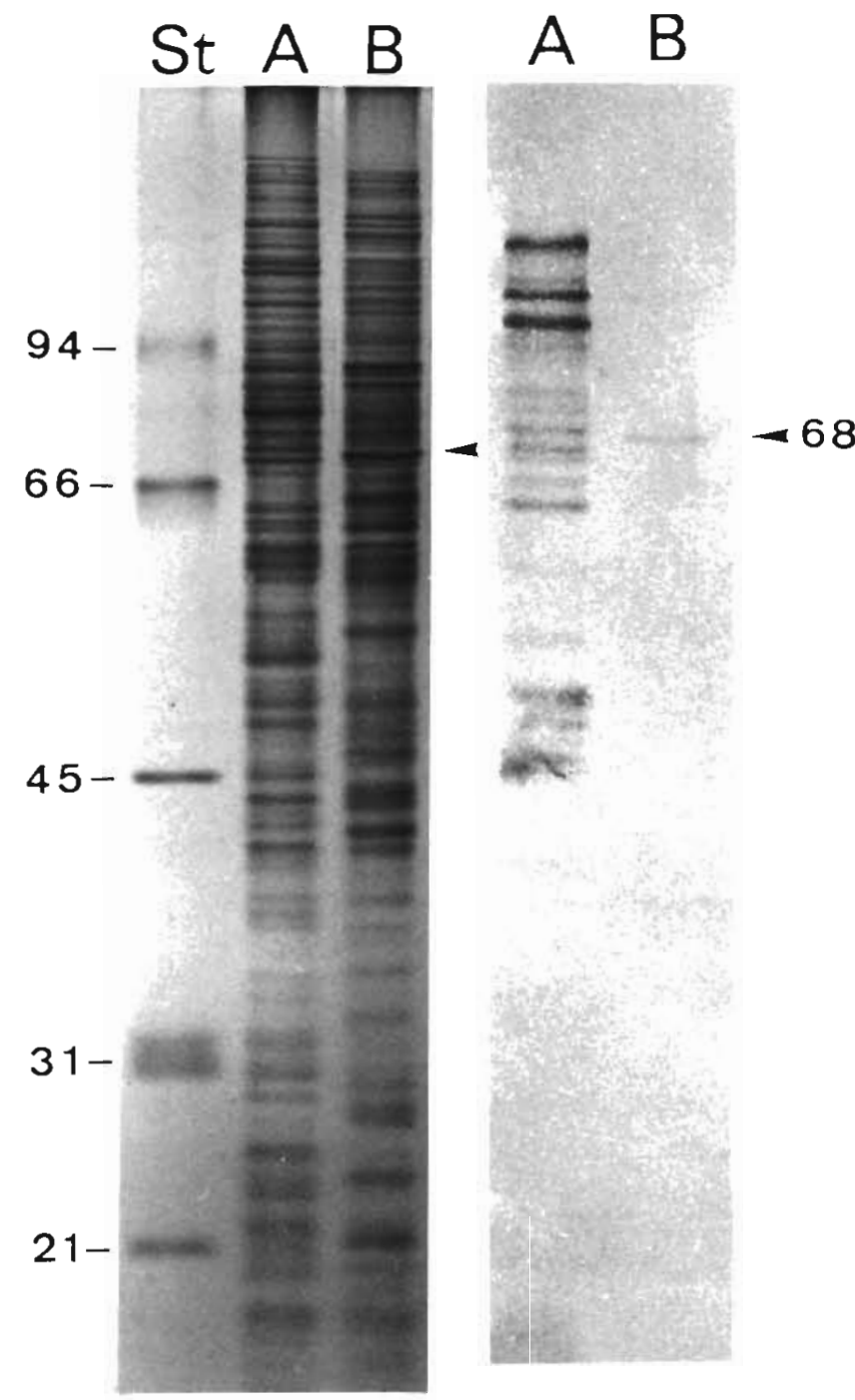

Fig. 1. SDS-PAGE of surface proteins of Corynebacterium aquaticum strains (left), and the corresponding Western blot analysis using the rabbit serum raised against $C$. aquaticum ATCC 14665 (right). Lanes: (St) Protein standards of known molecular weight; (A) strain RB 968BA; (B) strain ATCC 14665. Arrowhead shows a common antigenic protein band
ATCC strain which supports the finding of differences in the taxonomic tests. The Western blot assays indicated that both strains did share one major antigenic protein of $68 \mathrm{kDa}$ (Fig. 1A, B). As expected, the antisera from the $C$. aquaticum strains did not display any immunological reaction with the proteins of the clinical corynebacteria (data not shown). These results indicate, as previously reported (Baya et al. 1991, Bandín et al. 1992), that surface protein analysis, as well as immunoblot procedures, are useful tools to establish phenotypic and antigenic relatedness among Gram positive bacteria.

\section{Pathogenicity of Corynebacterium aquaticum for fish and mice}

The virulence assays demonstrated that the fish isolate of Corynebacterium aquaticum (strain RB 968BA) was pathogenic for striped bass and rainbow trout with mean $\mathrm{LD}_{50}$ values of $1.0 \times 10^{5}$ and $5.8 \times 10^{4}$ cells respectively (Table 2). As in the natural disease, the experimentally infected fish showed hemorrhaging in the brain cavity but no apparent external signs were observed. We recovered the Corynebacterium strain not only from moribund fish but also from all surviving bass and trout sacrificed $3 \mathrm{wk}$ post-infection. This suggests that the bacterium can establish a carrier state in these fish. The results of pathogenicity assays in mice showed that this strain can be also considered as virulent since it displayed an $\mathrm{LD}_{50}$ of $8.3 \times 10^{4}$ live cells. In contrast, the reference strain of $C$. aquaticum (ATCC 14665) was not pathogenic for either fish or mice. Of the 3 clinical corynebacteria included for comparison, only C. pseudotuberculosis was pathogenic for mice. This organism also exhibited a low degree of virulence for fish (Table 2).

Of interest was the finding that Corynebacterium aquaticum RB 968BA lost much of its virulence when stored for 6 mo by freezing rather than by serial passage in culture media (the $\mathrm{LD}_{50}$ values increased to $10^{7}$ and $10^{8}$ for fish and mice, respectively). It is not known if the loss in virulence occurred during frozen storage or during the re-culturing of the bacterium but it is known that spontaneous loss of virulence can occur during culture with some fish pathogens (Ellis et al. 1988).

\section{Biological activities of Corynebacterium aquaticum $\mathrm{ECP}$ in vivo and in vitro}

To evaluate the possible role of exotoxins in the virulence mechanisms of Corynebacterium aquaticum from striped bass, we determined the biological 


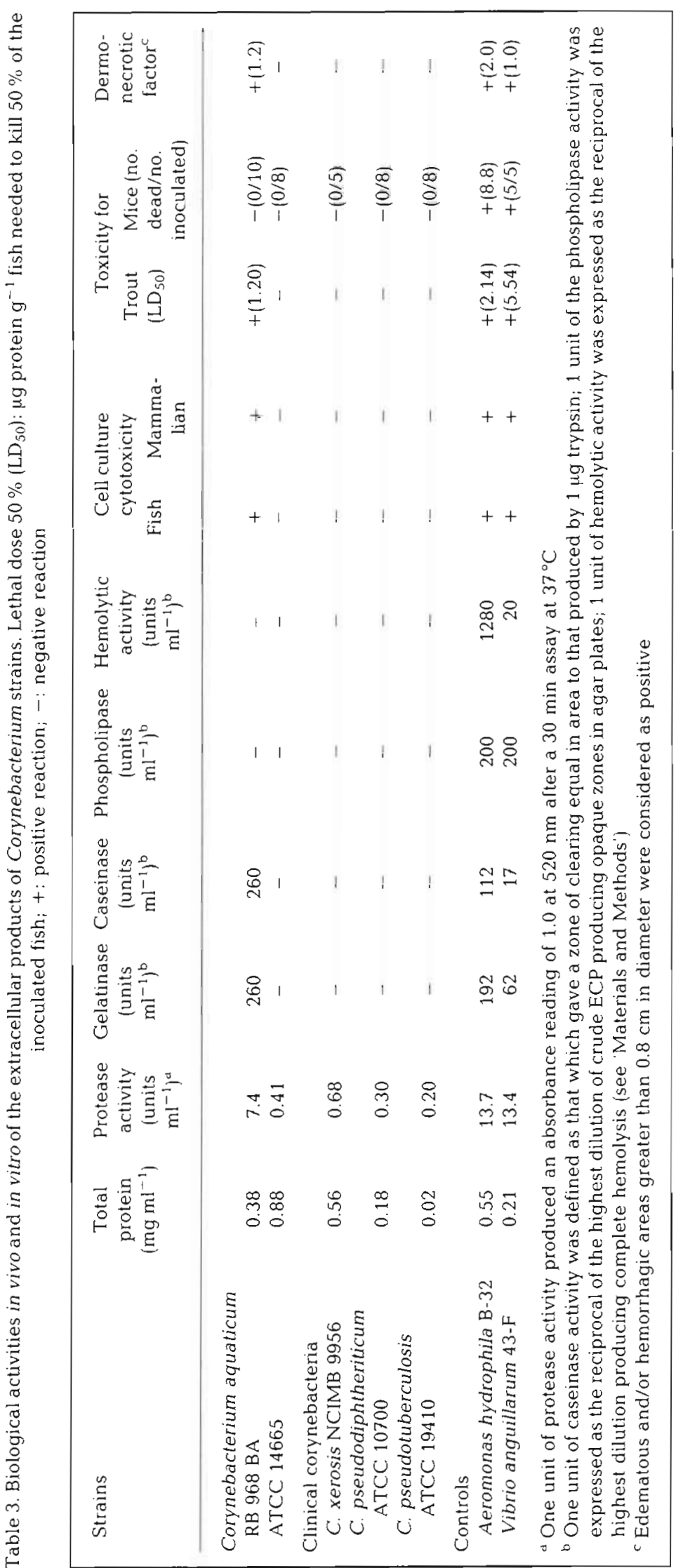


activities of its ECP and compared them with those shown by ECP of other Corynebacterium strains (Table 3). Although none of the strains exhibited phospholipase or hemolytic activities, the ECP of the striped bass isolate (RB 968BA strain) possessed high proteolytic activity with the production of caseinase and gelatinase, and were cytotoxic for all of the fish and homoiothermic cell lines tested. The smallest dose necessary to produce partial or total monolayer destruction ranged from 0.47 to $0.95 \mu \mathrm{g}$ protein $\mathrm{ml}^{-1}$ depending on the cell line.

The Corynebacterium aquaticum isolate from striped bass was the only strain that produced exotoxins with lethal effects for fish, mortalities occurring 24 to $48 \mathrm{~h}$ after inoculation. The $\mathrm{LD}_{50}$ value was $1.20 \mu \mathrm{g}$ protein $\mathrm{g}^{-1}$ fish which was comparable to that reported for other fish pathogens such as Aeromonas (Thune et al. 1982, Ellis \& Stapleton 1988, Santos et al. 1988), Vibrio (Kodama et al. 1985, Santos et al. 1991) or Serratia species (Baya et al. 1992). Although the ECP of this strain showed dermonecrotic activity in rabbits, it did not produce mortality in mice.

All of the biological activities exhibited in vivo and in vitro for the ECP of the fish isolate of Corynebacterium aquaticum were lost after heating $\left(100^{\circ} \mathrm{C}\right.$ for $\left.10 \mathrm{~min}\right)$.

Although the live cells of Corynebacterium aquaticum RB 968BA suffered a considerable decrease in ability to successfully proliferate within the host after being frozen for a long period in the laboratory (as mentioned above), the capability to produce in vitro exotoxins lethal for fish remained unaffected. The extracellular products obtained from the reference strain of Corynebacterium aquaticum (ATCC 14665), as well as from the clinical corynebacteria, possessed a very low proteolytic activity, did not produce cytotoxicity in cell-lines, and were not lethal for fish and mammals (Table 3 ).

Our results suggest that proteases play an important role in the pathogenicity of our isolate for fish. With other fish pathogenic bacteria, proteases and/or phospholipases are important in pathogenicity (Santos et al. 1988, Ellis 1991, Baya et al. 1992). None of the ECP from the Corynebacterium isolates contained a phospholipase and none caused lethality in mice (Table 3). Most investigations of extracellular virulence factors are based on the assumption that a pathogenic strain produces the same toxins in vitro as it does in vivo. However, the absence of a specific component in the ECP of a particular strain does not mean that this microorganism lacks the capacity to produce it in vivo. Moreover, during stressful periods, the fish host tissues may be depleted of a particular nutrient(s) and this may induce the production of a series of new enzymes needed by an invading bacterium to utilize other organic sources.
On the other hand, secretion of some exotoxins is dependent on the phase of growth of the bacterium and its cultural conditions (Wretling \& Heden 1973, O'Reilly \& Day 1983, Idali et al. 1991) while other toxins remain in the cytoplasm and are released only after cell lysis. In fact, when the ECP of Corynebacterium aquaticum from striped bass were collected at $24 \mathrm{~h}$ (instead of at $48 \mathrm{~h}$ ), the protein content and proteolytic activity of the ECP were very low $\left(0.2 \mathrm{mg} \mathrm{ml}^{-1}\right.$ and 1.2 units $\mathrm{ml}^{-1}$ respectively), no cytotoxins were detected, and the ECP lacked toxicity for fish.

\section{Histopathological studies}

Tissues of rainbow trout treated with live cells on ECP of Corynebacterium aquaticum RB 968BA were histologically examined to evaluate the changes produced in the different organs (Fig. 2). In fish injected with bacterial cells, the brain showed hemorrhages (Fig. 2a). The eyes also had extensive hemorrhaging, possibly caused by a breakdown of the capillary layer of the coroid (Fig. 2b). Hemorrhages were also found in the kidney which showed an increased number of melanomacrophage centers. Some glomeruli exhibited a proteinaceous exudate, and the renal tubules showed signs of hyaline droplet degeneration. The pulp of the spleen was edematous and there was an increase in the number of melanomacrophage centers present. The liver was the organ least affected; it showed a mild congestion and occasional caseous necrosis. No cellular changes were found in the pancreas, stomach, pyloric caeca or the intestine.

The changes produced by the extracellular products were quite similar to those caused by the bacterial cells. The most severe lesions in the spleen, kidney, and liver were observed in fish that had been inoculated with undiluted ECP samples (Fig. 2c, d). These findings suggest that exotoxins play an important role in the disease process. The severity of the congestion found in the spleen (the closest organ to the point of ECP injection) together with the fact that similar congestion occurred in bacteria-free spleens from fish inoculated with live cells supports this hypothesis. Although, in general, the histopathological results found in fish exposed to both live cells and ECP fit the lesions that are produced when a bacterial infection occurs in fish, the most striking finding was hemorrhaging in the brain and eyes. Similar damage to these organs has been described in infections of fish by Streptococcus species (Boomker et al. 1979, Miyazaki 1982) and extracellular toxins have been correlated with the majority of the specific signs of the disease (Kusuda \& Hamaguchi 1988). 


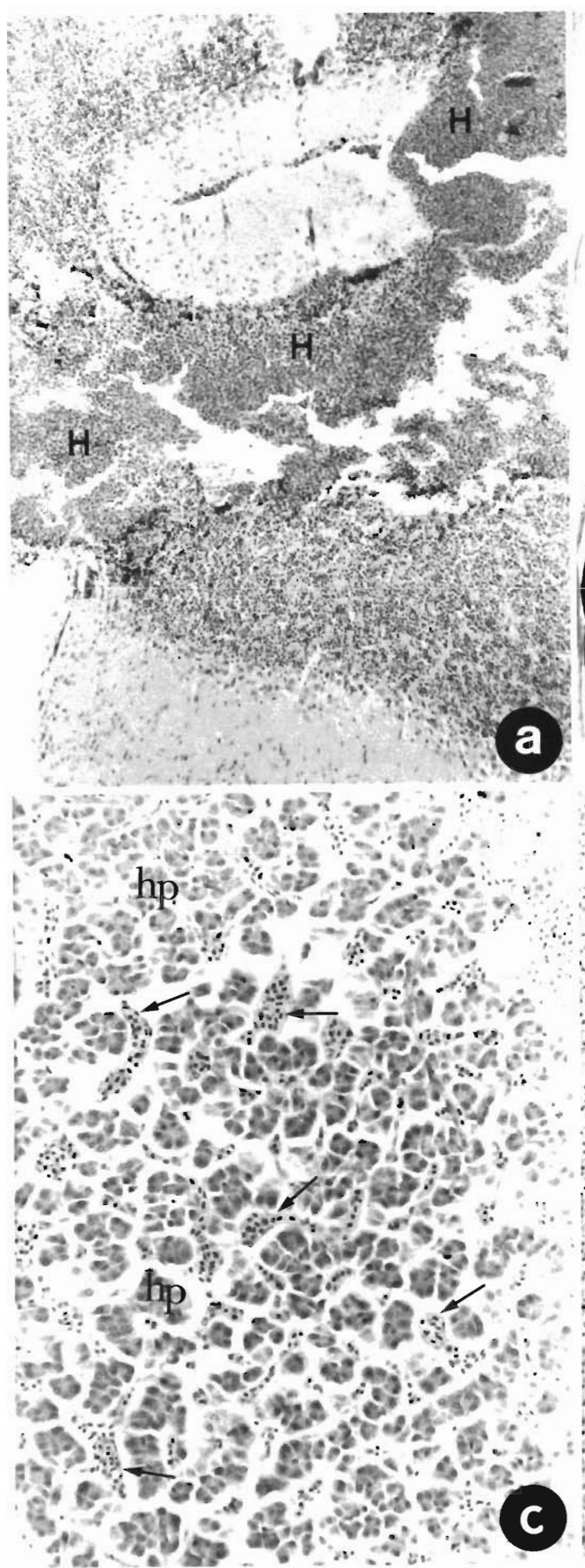

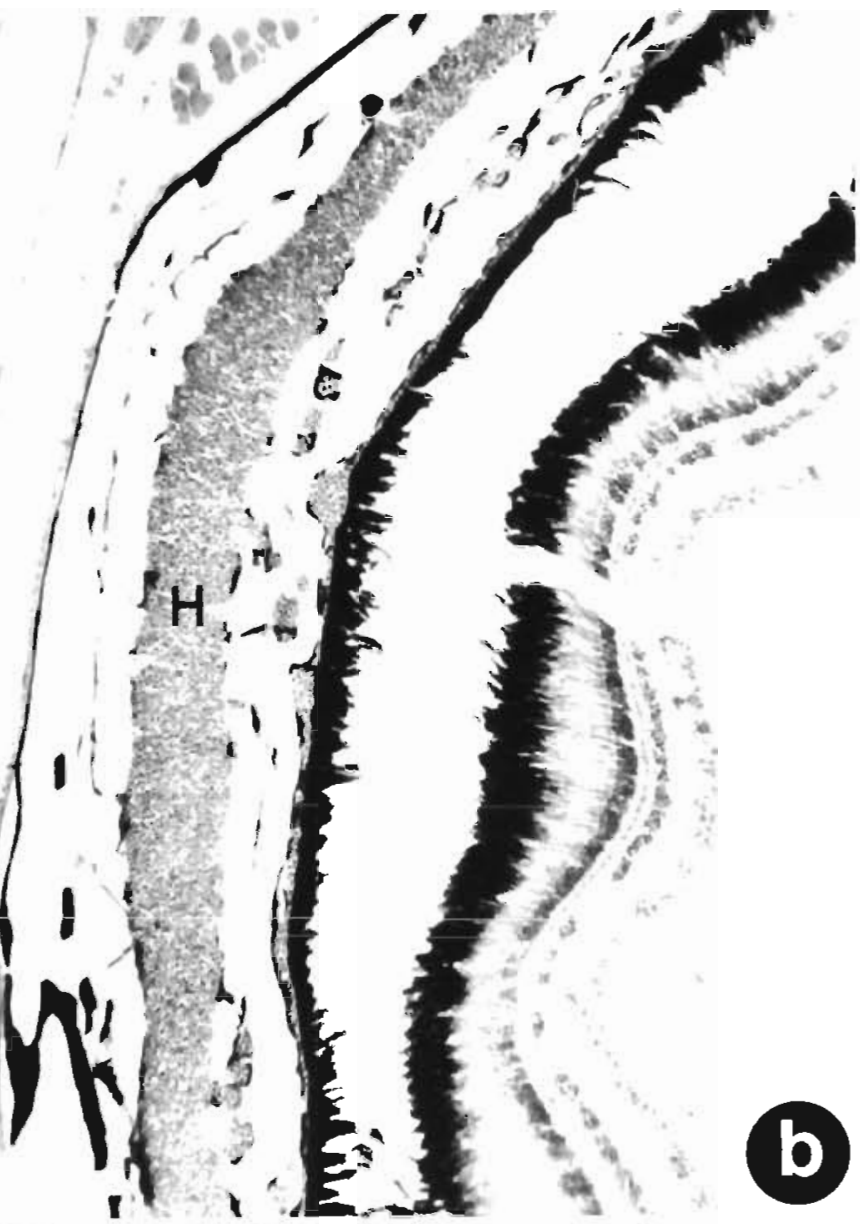
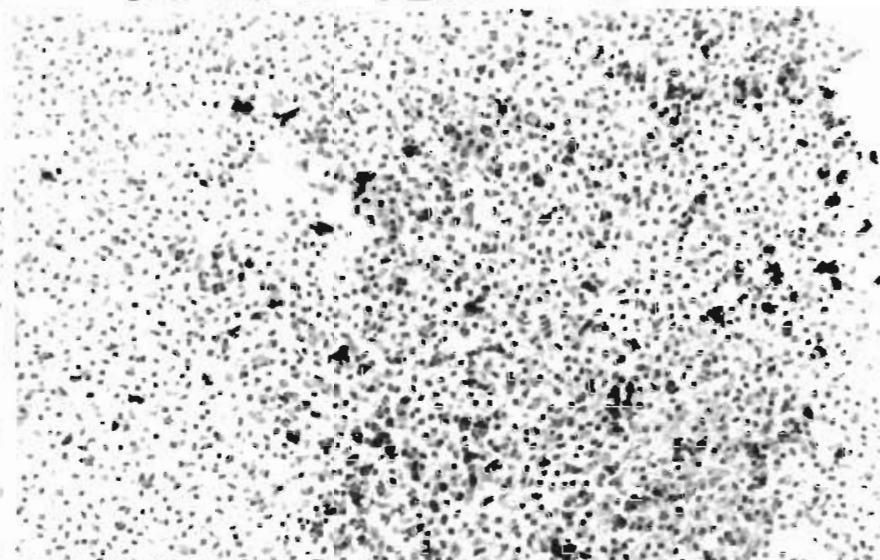

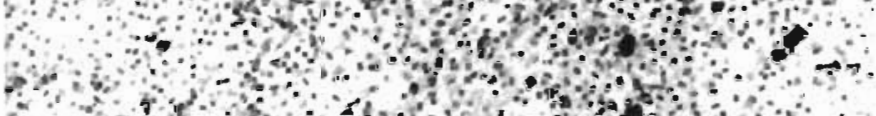

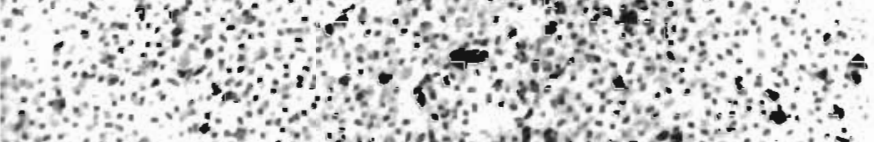

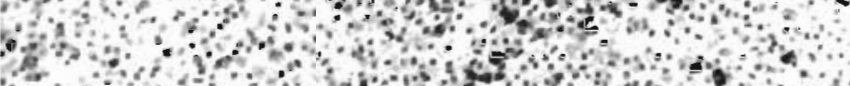

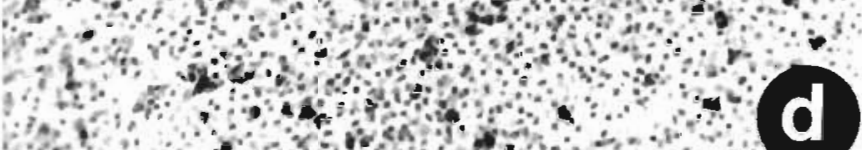

ond 


\section{Conclusion}

To our knowledge this is the first time that Corynebacterium aquaticum has been reported to be pathogenic for fish. Although $C$. aquaticum was first isolated from distilled water, it has been reported as a human pathogen affecting mainly immunocompromised patients. In humans, as in fish, the brain tissue can be involved.

It is not our intention here to announce the discovery of a new and important fish pathogen but we believe that Corynebacterium aquaticum should be recognized as an opportunistic fish pathogen, capable of producing disease when fish are stressed and nutrient conditions in the water supply are favorable. Also, the potential pathogenic capability for mammals exhibited by $C$. aquaticum in the present study, and its ability to establish a carrier state in fish, are findings that warrant future surveillance from a public health standpoint.

We believe that Gram positive bacilli warrant more attention from fish microbiologists. Currently, they are either overlooked because of their slow growth or simply considered as possible contaminants. They thus often end up being discarded when, in fact, they may be bona fide pathogens.

Acknowledgements. This investigation was supported in part by Grant MAR 91-1133-CO2-01 from the Direction General de Investigación Científica y Técnica (DGICYT) of Spain and by Grants F-179-89-008 from the State of Maryland, Department of Natural Resources (DNR), Sea Grant Award \# NA 90AA-DSG063, and Aquaculture enhancement fund from the Cooperative Extension Service, University of Maryland. I. Bandín was supported by the Ministerio de Educaión y Ciencia (MEC) of Spain. We thank the aquaculture facility of the Potomac Electric Power Company at Benedict, Maryland, for providing the juvenile striped bass used in this study.

\section{LITERATURE CITED}

Amos, K. H. (ed.) (1985). Procedures for the detection and identification of certain fish pathogens, 3rd edn, Fish Health Section, American Fisheries Society, Corvallis

Austin, B., Bucke, D., Feist, S., Rayment, J. (1985). A false positive reaction in the indirect fluorescent antibody test for Renibacterium salmoninarum with a 'coryneform' organism. Bull. Eur. Ass. Fish Path. 5: 8-9

Austin, B., Allen-Austin, D. (1985). Microbial quality of water in intensive fish rearing. J. appl. Bacteriol. (Symp. Suppl.): 207S-226S

Bandín, I., Santos, Y., Bruno, D. W., Raynard, R. S., Toranzo, A. E., Barja, J. L. (1989). Lack of biological activities in the extracellular products (ECP) of Renibacterium salmoninarum. Can. J. Fish. Aquat. Sci. 48: 421-425

Bandín, I., Santos, Y., Toranzo, A. E., Barja, J. L. (1991). MICs and $\mathrm{MBCs}$ of chemotherapeutic agents against Renibacterium salmoninarum. Antimicrob. Agents Chemother. 35: 1011-1113

Bandin, I., Santos, Y., Margariños, B., Barja, J. L., Toranzo, A. E. (1992). The detection of two antigenic groups among Renibacterium salmoninarum isolates. FEMS Lett. 94: (in press)

Baya, A. M., Toranzo, A. E., Lupiani, B., Li, T., Roberson, B. S., Hetrick, F. M. (1991). Biochemical and serological characterization of Corynebacterium spp. isolated from farmed and natural populations of striped bass and catfish. Appl. environ. Microbiol. 57: 3114-3120

Baya, A. M., Toranzo, A. E., Lupiani, B., Santos, Y., Hetrick, F. M. (1992). Serratia marcescens, a potential pathogen for fish. J. Fish Dis, 15: 15-26

Beckwith, D. G., Jahre, J. A., Haggerty, S. (1986). Isolation of Corynebacterium aquaticum from spinal fluid of an infant with meningitis. J. clin. Microbiol. 23: 375-376

Boomker, J., Imes, G. D., Camerson, C. M., Naude, T W. Schoonbee, H. J. (1979). Trout mortalities as a result of Streptococcus infection. Onderstepoort J. Vet. Res. 46. $71-77$

Bradford, M. M. (1976). A rapid and sensitive method for the quantitation of microgram quantities of protein utilizing the principle of protein-dye binding. Anal. Biochem. 72: 248-254

Brown, L. L., Albright, L. J., Evelyn, T P. T (1990). Control of vertical transmission of Renibacterium salmoninarum by injection of antibiotics into maturing female coho salmon Oncorhynchus kisutch. Dis. aquat. Org. 9: 127-131

Cahill, M. M. (1990). Bacterial flora of fishes: a review. Microb. Ecol. 19: 21-41

Collins, M. D., Cummins, C. S. (1986). Genus Corynebacterium Lahmann \& Neumann. In: Sneath, P. H. A., Mair, N. S., Sharpe, M. E., Holt, J. G. (eds.) Bergey's manual of systematic bacteriology. William \& Wilkins, Baltimore, p. $1386-1293$

Daily, O. P., Joseph, S. W., Coolbaugh, J. C., Walker, R. I., Merrell, B. R., Rollins, D. M., Seidler, R. J., Colwell, R. R., Lissner, C. R. (1981). Association of Aeromonas sobria with human infection. J. clin. Microbiol. 13: 769-777

Ellis, A. E. (1991). An appraisal of the extracellular toxins of Aeromonas salmonicida ssp. salmonicida. J. Fish Dis. 14 265-277

Ellis, A. E., Burrows, A. S., Stapleton, K. J. (1988), Lack of relationship between virulence of Aeromonas salmonicida and the putative virulence factors: A-layer, extracellular proteases, and extracellular haemolysins. J. Fish Dis. 11: 309-323

Evelyn, T. P. T., Ketcheson, J. E., Prosperi-Porta, L. (1986). Use of erythromycin as a means of preventing vertical transmission of Renibacterium salmoniarum. Dis. aquat. Org. 2: 7-11

Idali, C., Foged, N. T., Frandsen, P. L., Nielsen, M. H., Elling, F. (1991). Ultrastructural localization of the Pasteurella multocida toxin in a toxin-producing strain. J. gen. Microbiol. 137: 1067-1071

Fig. 2. Oncorhynchus mykiss infected with Corynebacterium aquaticum. Histopathological changes observed in the internal organs of rainbow trout experimentally infected with live cells $(\mathrm{a}, \mathrm{b})$ or treated with extracellular products (c, d) of $C$. aquaticum RB 968 BA. (a) Hemorrhagic areas in the brain (H); H\&E, 100x. (b) Intraocular hemorrhage (H); H\&E, 100x. (c) Mild congestion in the liver. The arrows show aggregates of erythrocytes among the hepatocytes (hp); H\&E, 200x. (d) Edematous and congested spleen; H\&E, 200X 
Kaplan, A., Israel, F. (1988). Corynebacterium aquaticum infection in a patient with chronic granulomatous disease. Am. J. med. Sci, 296: 57-58

Kodama, H., Moustafa, M., Mikami, T., Izawa, H. (1985). Partial purification of extracellular substance of Vibrio anguillarum toxigenic for rainbow trout and mouse. Fish Pathol. 20: 173-179

Krech, T., Hollis, D. G. (1991). Corynebacterium and related organisms. In: Balows, A. B., Hausler, W. J., Herrann, K. L., Isenberg, H. D., Shadomy, H. J. (eds.) Manual of clinical microbiology, 5th edn. American Society for Microbiology, Washington, D.C., p. 277-286

Kusuda, R., Hamaguhi, M. (1988). Extracellular and intracellular toxins of Streptococcus sp. isolated from yellowtail. Bull. Eur. Ass. Fish Pathol. 8: 9-10

Laemmli, U. K. (1970). Cleavage of structural proteins during the assembly of the head of bacteriophage T4. Nature 227: $680-685$

Lipsky, B. A., Golberger, A. C., Tomkins, L. S., Plorede, J. J. (1982). Infections caused by nondiphtheria corynebacteria. Rev. infect. Dis. 4: 1220-1235

Liu, P. V (1957). Survey of haemolysin production among species of Pseudomonas. J. Bacterioi. 74 : $718-727$

Miyazaki, T. (1982). Pathological study on streptococcicoses. Histopathology of infected fishes. Fish Pathol. 17: 39-47

Moore, W. E. C., Moore, V H. (1989). Index of the bacterial names and yeast nomenclature changes. American Society for Microbiology, Washington, D.C.

Olivier, G., Lallier, R., Larivière, S. (1981). Toxigenic profile of Aeromonas hydrophila and Aeromonas sobria isolated from fish. Can. J. Microbiol. 26: 330-333

O'Reilly, T., Day, D. F. (1983). Effects of cultural conditions on protease production by Aeromonas hydrophila. Appl. environ. Microbiol. 45: 1132-1135

Reed, L. J., Müench, H. (1938). A simple method of estimating fifty percent end points. Am. J. Hyg. 27: 493-497

Roberson, B. S. (1990). Bacterial agglutination. In: Stolen, J. S., Fletcher, T C., Anderson, D. P., Roberson, B. S., van Muiswinkel, W B. (eds.) Techniques in fish immunology. SOS Publ, NJ, p. 81-86

Santos, Y., Lallier, R., Bandín, I., Lamas, J., Toranzo, A. E. (1991). Susceptibility of turbot (Scophthalmus maximus), salmon (Oncorhynchus kisutch) and rainbow trout (O. mykiss) to Vibrio anguillarum live cells and their exotoxins. J appl. Ichthyol. 7: 160-167

Santos, Y., Toranzo, A. E., Barja, J. L., Nieto, T. P., Villa, T. G. (1988). Virulence properties and enterotoxin production of Aeromonas strains isolated from fish. Infect. Immun. 56: $3285-3293$

Responsible Subject Editor: T Evelyn, Nanaimo, B.C., Canada
Skerman, V. B. D., McGowan, V., Sneath, P. H. A. 1989) Approved lists of bacterial names (amended edn). American Society for Microbiology, Washington, D.C.

Smibert, R. M., Krieg, N. R. (1981). General characterization. In: Gehardt, P. R., et al. (eds.) Manual of methods for general bacteriology. American Society for Microbiology, Washington. D.C., p. 409-443

Tendler, C., Bottone, E. J. (1989). Corynebacterium aquaticum urinary tract infection in a neonate, and concepts regarding the role of the organism as a neonatal pathogen. J. clin Microbiol. 27: 343-345

Thune, R. L., Graham, T. E., Riddle, L. M., Amborski, R. L. (1982). Extracellular products and endotoxin from Aeromonas hydrophila: effects on age-O channel catfish. Trans. Am. Fish. Soc. 11:749-754

Toranzo, A. E., Barja, J. L., Potter, S. A., Colwell, R. R., Hetrick, F. M. Crosa, J. H. (1983a). Molecular factors associated with virulence of marine vibrios isolated from striped bass in Chesapeake Bay. Infect. Immun. 39: 1220-1227

Toranzo, A. E., Barja, J. L., Colwell, R. R., Hetrick, F. H., Crosa, J. H. (1983b). Haemagglutinating, haemolytic and cytotoxic activities of Vibrio anguillarum and related vibrios isolated from striped bass on the Atiantic coast. FEMS Lett. 18: $157-262$

Toranzo, A. E., Combarro, P., Conde, Y., Barja, J. L. (1985) Bacteria isolated from rainbow trout reared in fresh water in Galicia (Northwestern Spain): taxonomic analysis and drug resistance patterns. In: Ellis, A. E. (ed.) Fish and shellfish pathology. Academic Press, London, p. $141-152$

Toranzo, A. E., Baya, A. M. Roberson, B. S., Barja, J. L., Grimes, D. J., Hetrick, F. M. (1987a). Specificity of the slide agglutination test for detecting bacterial fish pathogens. Aquaculture 61: 81-97

Toranzo, A. E., Santos, Y., Lemons, M. L., Ledo, A., Bolinches, J. (1987b). Homology of Vibrio anguillarum strains causing epizootics in turbot, salmon and trout reared on the Atlantic coast of Spain. Aquaculture 67: 41-52

Towbin, H., Stachelin, T., Gordon, J. 1979). Electrophoretic transfer of proteins from polyacrylamide gels to nitrocellulose sheets: procedures and some applications. Proc. natl Acad. Sci. U.S.A. 76: 4350-4354

Tsai, C. M., Frasch, C. E. (1982). Staining of lipopolysaccharide in SDS-polyacrylamide gels using silver staining method. Annal. Biochem. 119: 115-119

Wretlind, B., Hedén, L. (1973). Formation of extracellular haemolysin by Aeromonas hydrophila in relation to protease and staphylolytic enzyme. J. gen. Microbiol. 78: $57-65$

Manuscript first received: January 29, 1992

Revised version accepted: July 15, 1992 